\title{
Ultra Groups as Social Space for Leisure
}

Authors' contribution:

A) conception and design of the study

B) acquisition of data

C) analysis and interpretation of data

D) manuscript preparation

E) obtaining funding

\section{Daniel Seabra}

Fernando Pessoa University, Porto, Portugal

ABSTRACT

The paper aims to demonstrate that violence is far from a regular practice in Ultra groups, despite its notorious visibility as transmitted by the media. The paper attempts to demonstrate that Ultra groups are a social space of leisure for young people, rather than a space for violence. Actually, having used observation through direct participation and having registered the discourses of Ultra group members, it is possible to demonstrate that life in these groups represents, for many, not only a break from difficult everyday life, but also the only and/or the most important moment of social leisure in their lives.

The object of this research was four Ultra groups who support the teams of Oporto City: Super Dragõe, Colectivo Ultras 95 (both support Futebol Clube do Porto), Panteras Ngeras (supporting Boavista Futebol Clube), and Alma Salgueirista (supporting Sport Comércio e Salgueiros). The research was based on observation through direct participation made among the groups over six years. Also conducted were 90 semistructured interviews, 20 autobiographical narratives, and surveys (sample 206 for estimated $n=1766$ ).

\section{Introduction}

Ultra groups have been attending Portuguese football stadiums since the 1980s and can be defined as groups that support a specific club, have their own name and specific place inside the stadium, and encourage their team through their cheers/chants, flags, banners, streamers, posters, synchronized clapping, waves, claxons, flares, smoke bombs, etc. (Pereira 2002).

These groups emerged in Portugal mainly through the influence of the so-called Ultra Movement that appeared in Italy in the late 1960s in a troubled social and political context. This movement resulted from the transfer of the militancy model guiding the actions of political parties mainly on the far left of the Italian political scene to the youth groups that supported their clubs in football stadiums. The Italian Ultra groups were also influenced in some ways by English hooliganism, which is partly responsible for certain types of violence caused by some members of these groups. 
In Portugal, the Ultra groups are in the news not so much for how they encourage their clubs but rather for the violent acts instigated by some of their members. Such news causes a certain social alarm and arouses a very negative general opinion about these groups.

The evident violence attributed to hooligans and some members of Ultra groups has been the main theme of the topic investigated within the social sciences. The first relevant research on hooliganism was carried out by Harrington (1968). Other important studies followed. The investigations of Taylor (1971, 1982), Clarke (1978), a group of sociologists at the University of Leicester (Dunning et al. 1992; Murphy et al. 1994), a group of psychologists from Oxford (Marsh et al. 1980), Armstrong (1998), and Spaaij (2006) are important milestones in the investigation of hooliganism. Robson's research (2000), focused on Millwall Hooligans, as well as Kerr's theoretical proposal (1994) towards the understanding of violence, both characterizing this phenomenon, are indeed, the core of violence investigation of these social groups.

However, Redhead (1991) calls attention to the appearance of several discourses on hooliganism which have become an "object" of study in the social sciences and have been featured in the media. Following Cohen's line of thinking (1973), Redhead also considered that persistent discourses on hooliganism generate a moral panic leading to the policing of these groups and a greater punishment for violence, spurring the growth and transformation of hooliganism itself (Redhead 1997). Redhead advocates a different approach to hooligans, proposing a comprehensive approach to them as subcultures and also the concept of clubcultures to contemplate the various dimensions of these groups, highlighting leisure as one of them (1997). Redhead fits football precisely in this leisure industry. In turn, Giulianotti (1999) also highlights the fun bonding experiences among the football fans he studied.

The social research carried out among Ultra groups supporting clubs of the city of Oporto revealed their importance as leisure opportunities for their members. Nonetheless, the strongest emphasis given to them continues to be the violence caused by some of the elements of these groups.

One of the objectives of this paper is to show that despite the publicity given to the violence of Ultra groups, it is statistically insignificant in the context of Portuguese football and not even considered a relevant motivation of the members of the investigated Ultra groups.

Instead, the investigated Ultra groups do not only serve the clear function of supporting their football clubs, they also provide their members with meaningful space and time for sociability, relaxation, and entertainment. The second objective of this paper is to highlight this often overlooked dimension.

\section{Research Methods}

The investigation was carried out with four Ultra groups supporting teams of Oporto: Super Dragões, Colectivo Ultras 95 (both supporting Futebol Clube do Porto), Panteras Negras (supporting Boavista Futebol Clube) and Alma Salgueirista (supporting Sport Comércio e Salgueiros). The research was based on observation made through direct participation among the groups over a six-year period. In addition, 90 semistructured interviews, 20 autobiographical narratives, and surveys were conducted (sample 206 for estimated $\mathrm{n}=1766)$.

\section{Research Results and Discussion}

The safety of football matches is observed by the Public Security Police (P.S.P.) in major cities, and by the National Republican Guard (G.N.R.) in other cities or medium-sized localities. This is an important factor to be taken into account because it is the National Republican Guard that has policed the most games in Portugal. The graph below calculates the number of incidents per year recorded by these two institutions. 


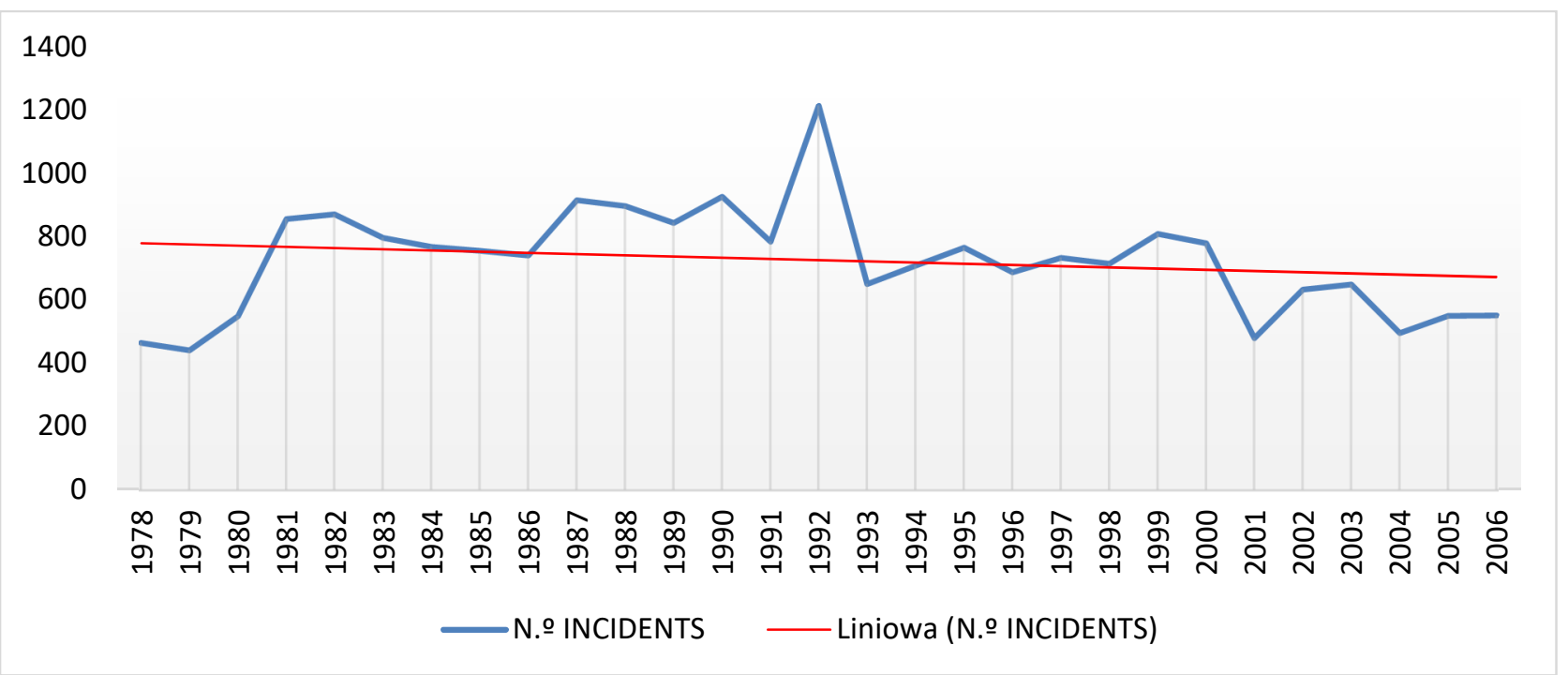

Figure1. Number of violent incidents per year

Source: Official numbers given by the Public Security Police and National Republican Guard

Taking as reference the year 1992, during which the highest number of violent incidents was recorded, there was a rising number of incidents in the transition from the 1970s to the 1980s. However, in 1993 there was a significant decrease, becoming more evident in the early years of the twenty-first century. Notably, the trending red line that the graph shows is decreasing. Almeida emphasized that the decrease in the number of violent incidents between 1987 and 1997 reached 20\% (2000, p. 10).

This descending tendency of violent incidents in Portuguese football can also be verified by the numbers given by the National Republican Guard referring to the years shown on the following graph. ${ }^{1}$

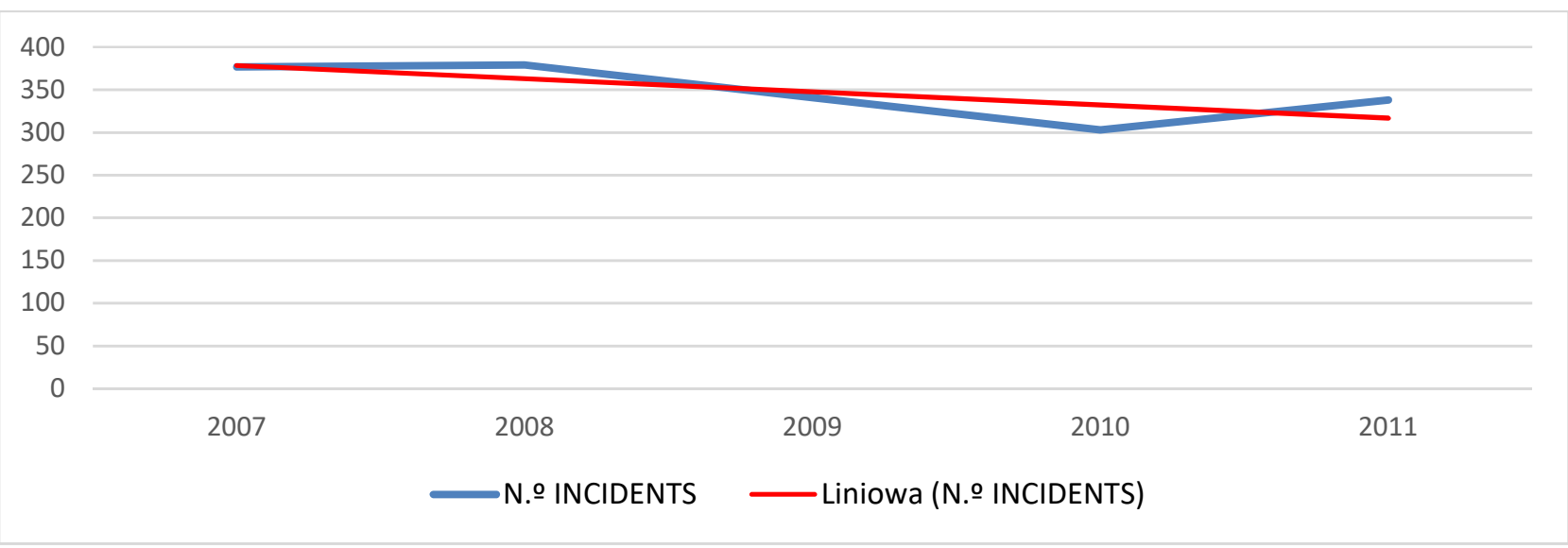

Figure 2. Number of violent incidents per year

Source: Official data by GNR

Another important aspect to consider is the percentage of football games where violent incidents occurred. Between 1978 and 1987, the percentage of match events ranged from 30\% in 1982 to 14\% in 1979 (Marivoet 1989, p. 7). If we consider the games played in the twenty-first century under surveillance of the GNR, and taking into account the year 2003, when the highest number of incidents was registered, it turns out that out of over 110,000 football games that were played, only $1.1 \%$ involved violent incidents.

\footnotetext{
${ }^{1}$ No available data by PSP
} 
According to the information, it seems clear that there is an evident downward trend in the number of violent incidents, assuming there is a residual value when you take into account the number of football matches taking place each year in Portugal. What should be stressed is that the vast majority of recorded violent incidents were caused by the general public attending the football games and not by members of Ultra groups, although some of them have at times engaged in serious and appalling acts. But is this the main reason that young people desire to belong to an Ultra group?

\section{Sociability and leisure as main reasons for belonging to Ultra groups}

In fact, the results of the questionnaire on the main motivation for joining an Ultra group highlights the groups' importance for their members, as we can verify in the following table.

Table 1. Motivations for belonging to ultra groups

\begin{tabular}{lccccc}
\hline MAIN REASON/MOTIVE & $\begin{array}{c}1^{\text {st }} \\
\text { OPTION }\end{array}$ & $\begin{array}{c}2^{\text {nd }} \\
\text { OPTION }\end{array}$ & $\begin{array}{c}3^{\text {rd }} \\
\text { OPTION }\end{array}$ & TOT. \\
\hline To support the club & 188 & 13 & 12 & 203 & 33 \\
To meet people and make new friends & 3 & 90 & 44 & 137 & 22 \\
To participate in the group's activities & 9 & 73 & 76 & 158 & 25 \\
To participate in the group's trips & 2 & 26 & 52 & 80 & 13 \\
To participate in violent acts & 1 & 3 & 27 & 31 & 5 \\
To steal & 1 & 1 & 2 & 4 & 1 \\
Other & 3 & 2 & 4 & 7 & 1 \\
\hline
\end{tabular}

Source: Results of survey conducted among the member of portoan Ultra Groups

The following results are based on the questionnaire on other opportunities that Ultra groups provide their members.

Table 2. Opportunities conferred by ultra groups

\begin{tabular}{lccccc}
\hline OPPORTUNITY & $1^{\text {st }}$ & $\begin{array}{c}2^{\text {nd }} \\
\text { OPTION }\end{array}$ & $\begin{array}{c}3^{\text {rd }} \\
\text { OPTION }\end{array}$ & TOT. & $\%$ \\
\hline OPTION & 33 & 28 & 34 & 95 & 15 \\
To watch the game more intensively & 96 & 52 & 32 & 180 & 30 \\
To have more fun during a match & 21 & 67 & 54 & 142 & 23 \\
To belong to a group & 51 & 51 & 67 & 169 & 27 \\
To participate in violent acts & 5 & 4 & 17 & 26 & 4 \\
To steal & 1 & 4 & 2 & 7 & 1 \\
\hline
\end{tabular}

Source: Results of survey conducted among the member of portoan Ultra Groups

As we can observe from the numbers, and even admitting the existence of an underrepresentation of motivations in favor of violence in our data (resulting from social, moral, and criminal censorship against violence), it is evident that the motivation to engage in violent acts and stealing is clearly criminal. This information was confirmed through observation, and not only were the acts of violence considered to be less frequent in these groups, they were also repeatedly carried out by a clear minority.

Instead of violence, the study results indicate the importance that sociability and leisure assume as motivations for belonging to the Oporto football Ultra groups. In fact, a considerable percentage of the members surveyed indicated the importance of the opportunity to become part of a group and travel with it, meet new people, and make new friends as their main motivations. Watching the game with more intensity and fun were also relevant motivations.

The field work clearly identified places and times for get-togethers and entertainment for the members of Ultra groups in every game. The rooms that are used as headquarters of the Ultra groups and which are normally located inside the stadiums of their club act as their meeting place before games. Apart from normal preparation for supporting the club during games, Ultra members chat and play cards, table football, or even 
PlayStation inside these rooms. In addition to their headquarters, some Ultra group members choose a coffee shop near their club's stadium as a place to get together before games.

But the bonding and fun between the members of Ultra groups is even stronger and more outstanding during their trips to the places they go to support their clubs. The long hours on buses provide a stronger familiarity. During these trips they sing their chants, play cards, and tell jokes, and there have even been brief sessions of striptease.

There are several statements by members of Ultra groups that show the environment of fun and good fellowship that everyone shares on these trips. One of them said that the trips are an opportunity "for a guy to have a few drinks and have a good time." Another recalled that he had spent a whole bus trip to Milan "drinking and playing cards." There are some unforgettable bizarre incidents that happen on some of these trips. One of them recalled the following trip to Lisbon:

"I remember a few years back going to Belem and leaving one of the guys behind in a service station on the highway. The journey continued. Then later we noticed one of them was missing. We didn't hear him talking. We had left him at the service station. He eventually made his way to Lisbon but on a bus full of drag queens that were going to Lisbon for a Drag Queen parade."

Another unforgettable trip was when the bus broke down in the middle of the highway just before arriving at the destination. Unable to continue by bus and knowing the game was soon to start, the group ran several kilometers on the main Portuguese highway to get to the game on time.

It is important to stress that these trips to the opponents' stadiums are the only chance some members of the Ultra groups get to travel. The survey carried out showed that $28 \%$ of the Ultra group members were students and $35 \%$ were from the working class, so it is not surprising that some of their members may only have the chance to travel through Portugal and other countries through the cheap trips that Ultra group organizations offer their members. During the study, it was easy to see the financial struggles some have experienced. Some of them go without money for food after buying the ticket to the game and paying for the trip. Others don't even have money to buy the ticket for the game. It is then that we see clear solidarity and gracious sharing among the group members. Sometimes the leaders of the groups buy the tickets and offer them to those who cannot afford them. Those who don't have money for food are also helped by their comembers as a way of paying for the tickets or just to share. It was even possible to see a coffee being shared among members.

But the interaction between group members does not only occur in the context of a football game. An Ultra group's anniversary dinner is a great moment of fellowship among all of the members. The Ultra group Colectivo Ultras 95 even organizes a football tournament to celebrate the group's anniversary between the teams formed by its members and members of the Ultra group Super Dragões, which supports the same club. In turn, the Ultra group Alma Salgueirista has even held some games with Ultra groups of other clubs with whom they have always had good fellowship.

The many socializing opportunities and long hours within the group are very important to many of its members. Considering the daily struggles they face due to their unsatisfactory professional state and even because of their young age, $72 \%$ of the Oporto Ultra group members are between 15 and 29 years old. There are many members who consider their most fun moments to have been spent with the group. One of them even admitted that "The best moments of my life were spent in the group. . . It's where I forget my problems." Another member also emphasized the importance of the group to him: "The group is my second body. It's my second skin."

Indeed, belonging to the group is of great importance to many of its members because it is within the group that great friendships start and others are strengthened. One of the leaders of the Colectivo Ultras 95 group said that the group's name was based on the great principle "that their friendship is above everything else." One of them even reported that he ended up getting divorced because his wife could not accept that he spent more time with his co-members than with her. He said: "The reason was I always wanting to be with my friends and getting drunk." In fact, a great number of members consider the Ultra group to be family.

In terms of family relationships, it's important to stress that some of them went beyond friendship. Some of the members dated and even got married. Other friendships that started during the time they belonged to the 
group remained throughout their lives. Inside these relationships between group members was discovered what could be considered a market to hire people to perform different services. In other words, if any of the members need a specific service from the likes of a plumber, a photographer, a mechanic, a lawyer, or an accountant, they try to find someone within their group who could do that service. An example is the collaboration between a businessman and an accountant that has lasted for years. This is, therefore, another dimension of the great friendships that are established between members of the Oporto Ultra groups.

For many of the group members, belonging to the group gives them their first major experience of belonging to a group or, using Anderson's words (1994), belonging to an "imagined community" that emerges from the support given to a club and that is able to create feelings of acceptance and recognition. Many youngsters, most of them from the working class and not always successful in school, find in their Ultra groups an alternative society (Revilla 1996) to their dominant one, which for several structural reasons sends them to the limit and to a long phase of transition that hampers and stalls their integration into the labor market and the acceptance of family responsibilities (Costa et al. 1996; Revilla 1996). It is within the group that they find time for socialization, entertainment, and excitement, breaking away from the daily life that they consider to be dull and uninteresting, from school, work, or a generally empty life with no perspectives (Revilla 1996). The time spent within the Ultra groups is therefore felt as a time of action, socialization, identification, and representation.

\section{Conclusions}

The groups that support the football clubs in Portugal emerged during the 1980s under the influence of the Italian Ultra Movement. But despite the active and militant way they support their clubs in every game, these groups of young supporters are better known for their acts of violence and vandalism.

However, the quantitative data that was gathered from the security forces responsible for the surveillance of football matches in Portugal show that violence carried out by the spectators of this sport in Portugal is on the decline. Furthermore, the figures also show that the percentage of football games in which there has been violence by spectators is merely residual. Therefore, violence does not exist to the extent that is indicated by the media and which is perpetrated by certain members of the Ultra groups. Although these members are dangerous and more visible, and therefore more shocking, they are clearly a minority when we consider the overall numbers for instances of violence caused by the majority of fans who go to football games in Portugal.

The research carried out on four Oporto club Ultra groups also revealed that violence is only a residual motivation for becoming a member of these groups. In fact, very few of them mention violence as the reason for belonging to their group. Evidence shows that supporting the club, the chance to meet people and make friends, and the chance to take part in the group's trips and activities are the main motivations for belonging to an Ultra group. The results also reveal that the Ultra groups are a fun place to be and act as an escape from members' everyday problems.

Apart from the results obtained through surveys, data collected through direct observation, as well as statements made by members of Oporto football club Ultra groups cited in this paper, help determine the importance that these groups have as a space/time of sociability and entertainment that helps members break away from a difficult, dull, and uninteresting daily life. For many of the young people who form them, Ultra groups represent an alternative society in which they can have fun, meet friends, and create social relationships that in some cases remain for life. There are also many who find in them the answer to the dilemmas of youth when transitioning to adulthood.

\section{REFERENCES}

Almeida, C. (2000). Relatório Nacional sobre a Violência no Desporto. Parte II./ National Report about Violence in Sports. Part II/. Desporto/Sport, January/February 3-19. Lisboa: Centro de Estudos e Formação Desportiva.

Anderson, B. (1994). Imagined Communities. London: Verso.

Armstrong, G. (1998). Football Hooligans: Knowing the Score. Oxford: Berg. 
Clarke, J. (1978). Football and Working class fans: tradiction and change. In R. Ingham, S. Hall, J. Clarke, P. Marsh, J. Donovan (Eds), Football Hooliganism. The wider context (pp. 37-60). London: Inter-Action Inprint.

Cohen, S. (1973). Folk Devils and Moral Panics. Herts: Paladin.

Costa, P., Tornero, J., \& Tropea, F. (1996). Tribus urbanas. El ânsia de identidad juvenil: entre el culto a la imagen y la autoafirmación a través de la violência /Urban tribes. The thirst for youth identity: between image worship and selfassertion for violence/. Barcelona: Ediciones Paidós Ibérica.

Dunning, E., Murphy, J., \& Williams, J. (1992). The Roots of Football Hooliganism: An Historical and Sociological Study. London and New York: Routledge \& Kegan Paul.

Giulianotti, R. (1991). Scotland's tartan army in Italy: The case for the carnivalesque. The Sociological Review, 39(3), 503-527.

Kerr, J. (1994). Understanding Soccer Hooliganism. Buckingham: Open University Press.

Marivoet, S. (1989). Evolução da violência associada ao desporto/ The evolution of violence associated to Sport (19781987)/. Lisboa: Direcção-Geral dos Desportos.

Marsh, P., Rosser, E., \& Harré, R. (1980). The Rules of Disorder. London, Henley and Boston: Routledge \& Kegan Paul. Murphy, P., Williams, J., \& Dunning, E. (1994). O futebol no banco dos réus/Football on Trial/. Oeiras: Celta Editora.

Pereira, L. (2002). Dicionário do Futebol. Manual do Adepto /Football dictionary. Handbook of the fan/. Lisboa: Booktree.

Redhead, S. (1991b). Some reflections on discourses on football hooliganism. The Sociological Review, 39(3), 479-486.

Redhead, S. (1997). Subcultures to Subcultures: An Introduction to Popular Cultural Studies.Massachusetts: Blackwell Publishers.

Revilla, T. (1996). Ultras e skinheads: La juventud visible. Imágenes, estilos y conflitos de las subculturas juveniles en España/Ultras and skinheads. The visible youth. Images, styles and conflicts of juvenile subcultures in Spain/. Oviedo: Ediciones Nobel.

Robson, G. (2000). “No One Likes Us, We Don't Care”: The Myth and Reality of Millwall Fandom. Oxford and New York: Berg

Spaaij, R. (2006). Understanding Football Hooliganism: A Comparison of Six Western European Football Clubs. Amsterdam: Vossiuspers UvA - Amsterdam University Press.

Taylor, I. (1971). Football mad: A speculative sociology of football hooliganism. In E. Dunning (Ed.), The Sociology of Sport: A Selection of Readings (pp. 352-377). London: Frank Cass \& Co. Ltd.

Taylor, I. (1982). Class, violence and sport: The case of soccer hooliganism in Britain. In H. Cantelon \& R. Gruneau (Eds.), Sport, Culture and the Modern State (pp. 39-96). Toronto: University of Toronto Press.

\section{AUTHOR'S ADDRESS: Daniel Seabra}

Fernando Pessoa University

Human and Social Sciences Faculty

Praça 9 de Abril, n. ${ }^{\circ}$ 349, 4249-004 Porto

Portugal

E-mail: das@ufp.edu.pt

Received: 10 January 2017; Accepted: 24 February 2017 